\title{
Green Banking Prospects in Bangladesh
}

\author{
Md. Mustafizur Rahman', Md. Ali Ahsan², Md. Motahar Hossain ${ }^{3}$, Meem Rafiul Hoq ${ }^{4}$
}

${ }^{1}$ M.Phil (Fellow), University of Rajshahi, Rajshahi, BANGLADESH

${ }^{2}$ Lecturer, School of Liberal Arts \& Science, University of Information Technology \& Sciences (UITS), Rajshahi, BANGLADESH

${ }^{3}$ Senior Lecturer, School of Business, University of Information Technology \& Sciences (UITS), Rajshahi, BANGLADESH

${ }^{4}$ Lecturer, School of Business, University of Information Technology \& Sciences (UITS), Rajshahi, BANGLADESH

\begin{abstract}
Green banking is the operation of the banking activities giving especial attention upon the social, ecological and environmental factors aiming at the conservation of nature and natural resources. Banks can be green through bringing changes in six main spheres of banking activities. Those are Change in Investment Management, Change in Deposit Management, Change in House Keeping, Change in the Process of Recruitment and Development of Human Capital, Corporate Social Responsibility (CSR), and Making Consciousness Among Clients and General Mass. Such an initiation can ensure a safe residence for upcoming generation. Bangladesh Bank has already issued circulars regarding this. Banks have already been asked to make their own green banking policy. Now we only need raising voice, keeping hand over hands, thinking in positive way and working in collective manner to make this a true.
\end{abstract}

Key Words: Green Banking, Green Policy, Green Products.

\section{INTRODUCTION}

A mong crores of skies of the Universe ours is the only planet capable of providing residence for animals. The reason behind this is the green environment of the planet enriched by green plants. This represents a close relationship between the animals and plants. But due to destructive activities of man as well as their strong tendency to grasp the nature, the color of our environment is becoming faded and the bio-diversity, residing there, is becoming eliminated. Because of the emission of Carbon in density and due to green house affect, the temperature of the whole world is increasing day by day. As a result, every year we are facing cyclones, floods, long drought, and many other natural disasters. To come out from this hazardous situation, the Green Banking activities taken by millions of banks of the world may play a vital role. Banking sectors are the main source of money for different commercial projects and those are working in bringing the economic development of a country. Green banking is nothing but the operation of the banking activities giving especial attention upon the social, ecological and environmental factors aiming at the conservation of nature and natural resources. Green bank promotes environmental and social responsibility but operates as a traditional community bank providing excellent services to investors and clients.1 A bank can grow itself as Green Bank through the application of environment friendly policies in every sector of its activities and through the elimination of Carbon foot prints 2 from its premises without changing main banking functions. Such bank acts as Ethical Bank, Moral Bank, Responsible Bank, and Sustainable Bank in a society.3 Green banking can facilitate both the clients, human capital and stake holders. This also increases the goodwill of the bank as a part of its image building activities. Although this theme has been implemented in several developed countries keeping a slo-

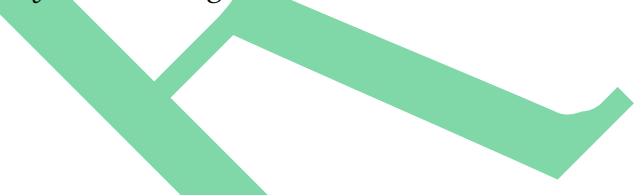

gan "Be Green, Go Green" before them, it has been started here in developing countries like ours in recent years. Several researchers have written about Green Banking. Among those most remarkable are Rashid (2010), Schultz (2010), Fenn (2012), Haque (2012), Hayder (2012), Hossan (2012), Khan (2012) and Millat (2012). This research is aimed at finding prospects of Green Banking in Bangladesh perspective.

\section{Objectives of the Study}

The major objective of the study is to analyze the prospects of green banking in Bangladesh. But the specific objectives of the study are to promote green banking among beneficiaries and in the banking sector. In particular, it is aimed to -

- To study management of environmental risk and identify opportunities for innovative environment friendly financial products.

- To study environmental and control regulations regarding green banking in Bangladesh.

- To design proper environmental management system in the investment projects.

- To create financial products and services that supports commercial development with environmental benefits.

\section{Methodology of the Study}

This article is mainly based on secondary data collected from several reliable sources. The sources of secondary data are annual reports of Bangladesh Bank and various Commercial Banks, and related articles etc. A thorough research was carried out for a period of three months when we talked with several bank bodies and finally this 
article is chalked. The investigation will be helpful for the readers and researchers.

\section{Justification OF THE STUDY}

Climate change is the most complicated issue the world is facing. Across the globe there have been continuous endeavors to measure and mitigate the risk of climate changes caused by human activities. Many countries over the world have made commitments necessary to mitigate climate change. As socially responsible corporate citizen, Bangladeshi banks have a major role and responsibility to support and supplement the government effort towards substantial reduction in carbon emission.

Normally we can consider the banks as environment friendly institution with their operational activities but it is important that the environment can be affected greatly by the activities of their customers. The banking sector is one of the major sources of financing for commercial projects 4 such as Brick field, Steel, Paper, Cement, Chemicals Fertilizer, Power, Textiles etc. Which cause maximum carbon emission. Therefore, the banking sector can play intermediary role between economic development and environment protection, for promoting environmentally sustainable and social responsible investment.

Green Banking refers to the banking business conducted in such areas and in such a manner that helps the overall reduction of external carbon emission and internal carbon footprint. To aid the reduction of external carbon emission, bank should finance green technology and pollution reducing projects. Internally the banking operations have considerably increased the carbon footprint of banks due to their massive use of energy e.g. lighting, air conditioning, electronic/electrical equipments, IT, high paper wastage, lack of green buildings etc.

Therefore, to adopting green banking, bank should adopt technology, process, and products which result in substantial reduction of their carbon footprint as well as develop sustainable business.

Now-a-days global worming is a key issue of the world and green banking might be the answer of this burning question. Assessing the available literature it has been found that no profound work has been done on this topic till now. As it is a very novice topic for country like Bangladesh. That's why working on this contemporary topic is important for the greater interest of people. In fact, the work has enormous justification from theoretical and practical view point.

\section{Review of Related Literature}

Md. Maruf Ullah found that as one of the least developed countries Bangladesh is the worst sufferer of world environmental pollution through industrialization of the western countries. Under such extreme environmental

Copyright $@$ 2013, Asian Business Consortium | ABR threat, the financial sector of Bangladesh is playing a key role as one of the important stake-holders of the economy enforcing the businessmen/ industrialists of the country to design their various strategy/action plans keeping in mind the crucial environmental issues. Green banking (GB) is a component of the global initiative by a group of stakeholders to save the climate/environment. In this study it is tried to find out the present status of green banking practices. In doing so a comparative analysis has been initiated among different types of banks [Stateowned Commercial Banks (SCBs), State-owned Specialized Development Banks (SDBs), Public Commercial Banks (PCBs) and Foreign Commercial Banks (FCBs)] in operation in Bangladesh to see whether they adopted green banking policy guided by Bangladesh Bank (BB). The study concluded that only PCBs, FCBs have adopted green banking guideline and financed some of green banking based projects on the other hand SCBs and SDBs initiatives are not remarkable. ${ }^{5}$

Md. Touhidul Alam Khan wrote an article on Green Banking: Go green, Think green. In his article he said that "in a word, we can say that green banking refers to the attempt of the banking sector to consider social, ecological and environmental factors with an aim to protect the environment and conserve natural resources". The banking sector plays a major role in financing investment for commercial projects, which is one of the most important economic activities for economic growth. Hence, by taking various measures to save the environment, the banking sector can play a crucial role in promoting environmentally sustainable and socially responsible investment. As such, Green Banking is also known as Ethical Banking and Sustainable Banking. The purpose of Green Banking initiatives taken by central bank is to ascertain required measures to save the environment and reduce pollution while serving or financing customers and improve in-house environment management through efficient and effective use of resources in all the branch and head offices of banks. Bangladesh Bank is well aware of the environmental degradation situation and has already given time-to-time directions to all scheduled banks. Commercial Banks are now required to ensure necessary measures to protect environmental pollution while financing a new project or providing working capital to the existing enterprises. Banks have been advised to facilitate their clients with utmost care financing for installation of Effluent Treatment Plant (ETP) in the industrial units and to finance in Solar Energy, Bio-gas, ETP and Hybrid Hoffman Kiln (HHK) in brick field under refinance program of Bangladesh Bank.

Green Economy is one whose growth in income and employment is driven by public and private investments that reduce carbon emissions and pollution, enhance energy and resource efficiency, and prevent the loss of biodiversity and ecosystem services. These investments need to be catalyzed and supported by targeted public expenditure, policy reforms and regulation changes. This is why Green Banking initiatives by all banks are a moral obligation to save the people. And the time has come for all lenders to 
"go green" and "think green" by setting their mindset taking remarkable footsteps through successful green banking initiatives. ${ }^{6}$

Khondokar Morshed Millat et. al had a study on Green Banking in Bangladesh Fostering Environmentally Sustainable Inclusive Growth Process. They said that Bangladesh is perusing low-carbon green development without compromising the imperative of faster economic growth and social development. Development strategies of the Government of Bangladesh laid down in the perspective plan (2010-2021) and the Sixth Five Year Plan (FY 2011-15) declare clear commitment of pursuing sustainable growth. The country's vulnerability to floods, cyclones and to the threat of inundation of large coastal areas from global worming driven sea level rise makes sustainability a prime development concern.

Financial practices can crucially influence the speed of adaptation of environmentally sustainable output practices in the real economy. Aware of its responsibility practices in the financial sector, Bangladesh Bank, the central bank of Bangladesh, has spearheaded adaptation and promotion of green ban banking practices throughout the financial sector, towards safeguarding environmental sustainability. As a regular financial sector, the central bank already proceeded a long way in implementation green banking. Banks in Bangladesh have enthusiastically responded to Bangladesh Bank's guidance towards green banking, with steps in environmentally responsible financing that are beginning to make profound impact on environmental practices in the real economy.

The central bank issued policy guidelines for green banking on February, 2011. According to the guidelines, all operating banks and financial institutions need to take effective measures to conduct environment friendly banking activities in the country. Bangladesh Bank has also issued a common reporting format to all the commercial banks to report green banking activities including the extent of carbon footprint in a structured way. Banks and financial institutions now regularly submit a quarterly report to Bangladesh Bank on their performance of green banking activities. ${ }^{7}$

\section{Results AND Discussion}

The aim of Green Banking can be reflected through taking a work plan to bring changes in six main spheres of whole banking activities. Banks should be promised in bringing such changes.

\section{MAJOR FINDINGS}

\subsection{Change in Investment Management}

$\circ$ Finance in Environment Friendly Projects: Banks should ensure finance in projects those are environment friendly or ethical in nature. ${ }^{8}$ It is necessary to give especial concentration upon their financing so

Copyright (C) 2013, Asian Business Consortium | ABR that the project or any of its parts they have taken or are going to take in hand will not be threat for the environment. Investment should be increased for projects installing solar energy plant, bio-gas, and/or other renewable energy plants, bio-fertilizer plants, Effluent Treatment Plant (ETP), Hybrid Hoffman Kiln projects for the production of brick etc. At lower interest and utmost care. ${ }^{9}$ They should take proper steps in shielding the production of hazardous Carbon from their projects. Encouraging farmers to grow salinity or flood tolerable species while providing them agro-investment and providing this at lumpsum interest is also the part of Green Investment.

- Investment in Waste Management Projects: Banks should invest in projects to manage waste materials harmful for environment especially produced by those mills and factories draining such components to rivers, rivulets, canals, beels and/or other water bodies and continuously doing harm to the environment. They should ensure proper management of wastes bringing necessary chemical changes in components to make it environment friendly through their projects.

Environmental Risk Rating before Investment: Banks should invest in a project after assessing its environmental or climatic risk. They should rate the presence of factors harmful for environment and its degree. Investment should only be given after being insured about the proper management of those harmful components. Banks can bring Green Home Loan, Green Car Loan and other newer products in this regard.

\subsection{Change in Deposit Management}

- Implementation of Alternative Delivery Channel and On-line Banking: Now days Alternative Delivery Channels are ensuring modern banking facilities. Most common Alternative Delivery Channels are ATM card, credit card, debit card, mobile banking, on-line banking, internet banking etc. BACPS (Bangladesh Automated Cheque Processing System) and BEFTN (Bangladesh Electronic Fund Transfer Network) etc. implemented by Bangladesh Bank has enhanced the services provided through Alternative Delivery Channel. Such products in one hand have sped up the services taken by the clients and in other hand have lessened the use of paper materials ensuring the freshness of nature.

○ Making every Deposit Products Environment Friendly: Deposits of clients are the main sources of money for every bank. So, banks provide different deposit services to their clients. All of such deposit products should be made environment friendly and should be brought under on-line management.

\subsection{Change in House Keeping}

Uses of papers encourage flattening of plants and leads the environment to destruction. Considering this, banks 
should lessen the use of papers otherwise introduce the use of recyclable papers. They should stop unnecessary printing and in need print on both sides of a paper and use eco-fonts while printing. Storage of all necessary information should be ensured through establishing electric data bank like EDW or Enterprise Data Warehouse. Etendering system should be introduced in purchasing necessary stationeries and other items for the institution. Office order, notice, account statement, invitation letter, thanking letter should be taken under electronic system like E-mail and mobile SMS etc. Meeting should be carried on through Video/Audio Conferencing rather than physical visit. Necessary steps should be taken while making the office electricity sustainable. Ensuring the use of day light instead of the use of electric bulb and ensuring proper ventilation instead the use of ACs may save energy. Energy saving bulbs can be used in need. Unnecessary use of light, fan, AC and computer etc. should be stopped. Electricity supply to the office premises should be ensured through utilization of solar energy and/or other renewable energies. Water and gas should be used sustainably. Overall environment should be kept neat and clean and free from any form of pollutants. All the staff members should be made conscious in this regard.

\subsection{Change in the Process of Recruitment and De- velopment of Human Capital}

Banks should start E-recruitment system while recruiting human capital. They can provide salary and bonus etc. through on-line system and can grow their human capitals as environment specialists and welfare worker along with making them skilled bankers. Skills and consciousness can also be developed through arranging seminars and symposiums time to time. Dividing the whole human capital of the institution into several clusters or groups and involving them in different environment friendly activities may help the proper implementation of Green Banking.

\subsection{Corporate Social Responsibility (CSR)}

Now days every bank is playing vital roles in CSR concern. This is the responsibility of an institution upon society where it is established. CSR can act in the following way in establishing Green Banking -

- Funding to combat against climatic change: Banks can make especial funds to combat against climatic change and ensure its proper utilization. They can help environmentalist NGOs or other such organizations through this fund. Internal human resources of the bank can also play roles in this regard.

- Combat against Natural Disasters and assisting thereafter: Banks can play direct or indirect roles in combating natural disasters. Providing monetary supports, relief goods and interest free loans etc. after such diverse situation will assist the victims to survive in the newer environment.

- Policy Formulation and Report Making: Banks should formulate policies and make reports on Green
Banking and analyze those reports to take necessary steps to ensure green environment through CSR.

\subsection{Making Consciousness Among Clients and General Mass}

Banks should arrange several seminar and symposiums to make their clients conscious regarding Green Banking as well as to introduce their Green Products and advantages therein. This can ultimately make the clients habituated to the Green Banking activities.

Every small 'GREEN' step taken today would go a long way in building a greener future and that each one of them can work towards to better global environment. ${ }^{10}$ Considering this Bangladesh Bank has issued BRPD Circular No. 2 on 27 February 2011 as an initiation to start Green Banking in our country through providing necessary directions. Through this circular all banks are asked to formulate their own Green Banking policies. According to this circular every bank will implement Green Banking through 3 distinct phases of three years work plan. The first of which consists Policy Formulation and Governance, Incorporation of Environmental Risk in CRM, Initiating In-house Environment Management, Introducing Green Finance, Creation of Climate Risk Fund, Introducing Green Marketing, On-line Banking, Supporting Employee Training, Consumer Awareness and Green Event, Disclosure and Reporting of Green Banking Activities. Second step consists Sector Specific Environmental Policies, Green Strategic Planning, Setting up Green Branches, Improved In-house Environment Management, Formulation of Bank Specific Environmental Risk Management Plan and Guidelines, Rigorous Programs to educate clients, and Reporting of Green Banking Activities. And in third step banks are asked to Design and Introduce Innovative Products and Report in standard Format with External Verification. ${ }^{11}$ Already we have passed the time for first two phases and in 2013 we are stepping to implement the third phase. As per Bangladesh Bank, 41 of the 47 commercial banks have formulated policy for Green Banking, 45 have formed Green Banking unit. In the year 2012 the budget allocation of top ten banks for Green Finance was EXIM Bank- BDT 2500 million, BASIC BankBDT 1200 million, Bank Asia- BDT 1200 million, Social Islami Bank- BDT 1040 million, Standard Chartered BankBDT 1000 million, Shahjalal Islami Bank- BDT 992.5 million, One Bank- BDT 729.56 million, Islami Bank- BDT 542.37 million, Agrani Bank- BDT 500 million and Al-Arafah Islami Bank- BDT 500 million respectively. Among 8059 branches of banks 3967 branches (38.03\%) have started online service. 38 banks have made their structure fully automated and providing on-line service through all their branches. 91.50 percent of private commercial banks are providing their clients on-line service, 1.39 percent are providing iBanking service and 1.37 percent are providing mobile or SMS banking service. 
We can step our foot keeping following slogans before us -

"Save paper, save trees", "Conserve energy, conserve natural resources", "Pay your bills online", "Turn off the tap when not needed", "Always use a cloth bag", "Reduce, reuse and recycle", "Digitize yourself", "Think before you press the button", "Everything has two sides", "Be paperless-kick the habit", "Use car pools to go to work", "Unplug electronic devices while not in use" etc.

\section{Conclusion}

Bangladesh Bank has issued different circulars time to time regarding modernization of Green Banking practice and its proper implementation. If every bank formulate their work plan following those rules and works collectively only then it will be possible to complete implementation of Green Banking activities in Bangladesh. It will then help earth in regaining Green Environment and ensure safe residence for our off-springs. Only the collective approach of both the clients and bankers can make this a true.

\section{REFERENCES}

Anonymous. 2012. Green Banking an avenue to safe environment. http://www.thefinancial bd.com/more.php?news_id $=132169 \&$ date $=2012-06-08$. 08 February 2013.
Fenn, K. 2012. All about Green Banking. http:/ /www.preventclimatechange.co.uk/green-banking.html. 08 February 2013.

Haque, A.N. 2012. Green Banking Initiatives in Bangladesh. The Independent. 2 December 2012.

Hayder, M.M. 2012. Green Banking and its Practices in Bangladesh. Term Paper, Department of Finance and Banking, University of Chittagong. 35pp.

Hossan, F. 2012. Green Banking. The Daily Star. 18 November 2012.

Khan, M.T.A. 2012. Green Banking: go green, think green. http://www.thedailystar.net/ suppliments/2012/environment/pg1.htm. 08 February 2013.

Millat, K.M. and Others 2012. Green Banking in Bangladesh Fostering Environmentally Sustainable Inclusive Growth Process. http://www.bangladesh-bank.org/pub/ special/greenbankingbd.pdf. 31 December 2012.

Rashid, M. 2010. Eyes on Green Banking. http:/ / www.thedailystar.net/newDesign/newsdetails.php?nid=141510. 08 February 2013.

Schultz, C. 2010. Green Bank Report. http://greenbankreport.com/green-bank-deals/what-is-themeaning-of-green-banking/. 08 February 2013.

Ullah, M.M. 2010. Green Banking in Bangladesh- A Comparative Analysis. http://www.wbiconpro.com/610-Maruf.pdf. 20 February 2013.

Wikipedia. 2013. Ethical Banking. http://en.wikipedia.org/wiki/Ethical_banking. 08 February 2013. 